\title{
Traditional fertilization and its effect on corn insect populations in the Guatemalan highlands
}

\author{
Helda Morales ${ }^{\mathrm{a}, *}$, Ivette Perfecto ${ }^{\mathrm{b}}$, Bruce Ferguson ${ }^{\mathrm{c}}$ \\ a Departamento de Agroecología, El Colegio de la Frontera Sur, Carretera Panamericana y Periférico Sur, Apartado Postal 63, \\ CP 29290, San Cristóbal de Las Casas, Chiapas, Mexico \\ b School of Natural Resources and Environment, Dana Building 430 E, The University of Michigan, \\ Ann Arbor, MI 48109-1115, USA \\ ${ }^{\mathrm{c}}$ Biology Department, Natural Sciences Building, The University of Michigan, Ann Arbor, MI 48109, USA
}

Received 18 May 1999; received in revised form 25 April 2000; accepted 3 July 2000

\begin{abstract}
Cakchiquel farmers in Patzún, Guatemala stated that pest populations have increased in corn crops since they abandoned organic fertilization and adopted synthetic fertilizers. Given the dearth of scientific information about the effects of fertilization practices on pests, a controlled experiment was performed to elucidate these interactions. Pests, their natural enemies, and nutritional status were compared among corn plots with synthetic and organic fertilizers, and a control without fertilizer. Corn in fields treated with organic fertilizer applied for at least 2 years hosted fewer aphids (Rhopalosiphum maidis) than corn treated with synthetic fertilizer. This difference seems attributable to high concentration and total content of foliar nitrogen in corn in the synthetic fertilizer plots, although numbers of Spodoptera frugiperda showed a weak negative correlation with increased nitrogen levels. Coccinellidae populations were higher in plots with high aphid populations, but only where organic fertilizer was applied. There were no significant yield differences among treatments. (C) 2001 Elsevier Science B.V. All rights reserved.
\end{abstract}

Keywords: Pest management; Fertilizers; Compost; Corn; Insect-plant interactions; Traditional knowledge; Guatemala

\section{Introduction}

The majority of Cakchiquel farmers responding to a survey conducted in Patzún, Guatemala, did not recognize herbivorous insects as a problem in their milpas (corn (Zea mays) intercropped with beans (Phaseolus vulgaris), fava (Vicia fava), and/or squash (Cucurbita maxima, C. pepo)) (Morales and Perfecto, 2000). The farmers attributed this lack of pests to preventive agricultural practices, such as soil man-

\footnotetext{
${ }^{*}$ Corresponding author. Tel.: +52-967-81883, ext: 4217; fax: +52-967-82322.

E-mail address: hmorales@sclc.ecosur.mx (H. Morales).
}

agement. Patzún farmers traditionally mixed ashes, kitchen scraps, crop residues, weeds, leaf litter, and manure to produce compost. Around 1960, synthetic fertilizers were introduced and rapidly adopted in the area. Today the majority of farmers have replaced organic fertilizers with urea $\left(\mathrm{CO}\left(\mathrm{NH}_{2}\right)_{2}\right)$, although some recognize the negative consequences of the change and complain that pest populations have increased in their milpas since the introduction of the synthetic fertilizers (Morales, 1998).

Previous studies showed that plants with sufficient nutrients were stronger, healthier, and in general better able to compensate for pest damage than those under nutritional deficiencies (Teetes, 1980; Listinger, 1993). 
On the other hand, because plants provide nutrients to herbivorous insects, an increase in the nutrient content of the plant is likely to increase its acceptability to pest populations (Scriber, 1984; McGuinness, 1987). Lightfoot and Whitford (1987) found that variation in herbivore response may be explained by the feeding behavior of the herbivores: with increasing nitrogen concentrations in creosotebush (Larrea tridentata) plants, populations of sucking insects increased, but chewing insects declined. With higher nitrogen fertilization, the amount of nutrients in the plant increases, as well as the amount of secondary compounds that affect herbivores (Herms and Mattson, 1992). These protein digestion inhibitors are accumulated in vacuoles that are not consumed by sucking herbivores, but harm chewing herbivores (Raven, 1983).

Proponents of organic agriculture, as well as interviewees in Patzún, have for many years attributed increased pest damage to inorganic fertilizers (Howard, 1943). Plant pathologists have established that organic fertilizers can reduce nematode and pathogen attacks (Hoitink et al., 1993). Efforts by entomologists to evaluate the effects of fertilization on insect pest populations have not been conclusive. Some evidence supports the observation that organic fertilizers diminish herbivorous insect populations (Culliney and Pimentel, 1986; Eigenbrode and Pimentel, 1988; Listinger, 1993; Phelan et al., 1995), whereas other reports suggest that organic fertilizers do not always diminish pest populations but even increase them (Costello, 1994; Costello and Altieri, 1995; Letourneau et al., 1996). There clearly is a lack of understanding of the relationship between organic fertilization and insect pests.

If studies comparing pest populations between plants treated with synthetic fertilizers and plants treated with organic fertilizers are scarce and contradictory, the understanding of the mechanisms involved in the process is almost non-existent. Understanding the effects of traditional fertilization compared with synthetic fertilizers would allow better design and management of agroecosystems. Furthermore, understanding traditional agricultural practices would hopefully contribute to the empowerment of farmers and improve communication between farmers and extensionists (Altieri, 1984; De Walt, 1994).

In an attempt to understand traditional Cakchiquel pest management practices, a controlled experiment was made to elucidate the effects of crop fertilization on pests. Pests, their natural enemies, and nutritional status were compared among corn plots fertilized with synthetic and organic fertilizers. This is the first study that compares the effect on pests of traditional organic fertilization with inorganic fertilization in farmers' fields, using traditional farming techniques.

\section{Methods}

Between 1995 and 1997 controlled experiments were established in the highlands of Guatemala in three sites, two in farmers' fields in Panimaquím and Patzún, and one at the experimental station of the Institute of Agricultural Science and Technology (ICTA) in Chimaltenango, Guatemala. Working in farmers' fields permitted evaluation of the treatments within the context of traditional management and local environmental conditions, whereas the plots at ICTA assured greater control over the treatments.

\subsection{Sites and agronomic management}

The three sites were located in the Department of Chimaltenango, in the western Guatemalan highlands. The majority of the Cakchiquel population in the area cultivate traditional milpas as well as non-traditional export crops. All three sites had fairly rich volcanic soils, but differed in altitude, climate, and in the way that the farmers managed the soil. Different crops had been planted at the three sites, and different fertilizers had been applied. The quantities of fertilizer applied to the sites before the study was unknown.

The first site was located in the village of Panimaquím at $2400 \mathrm{~m}$ above sea level. Alejandro Cipac, the owner of the plot, planted his milpa in May and harvested it in January or February. Like everyone else around, he sowed four corn and two bean seeds in a hole made with a hoe. These four corn plants growing together are a "postura". Compost, combining any available materials (ashes, lime, crop residues, weeds, and manure from goats, cows, horses, rabbits, and chickens in a mulch pile) was mixed into the soil at planting. When there was not enough compost, synthetic fertilizer (15-15-15) was used at a rate of approximately $0.05 \mathrm{~kg}$ for each "postura" $\left(425 \mathrm{~kg} \mathrm{ha}^{-1}\right), 3$ weeks after the germination of the 
corn. Since the introduction of the non-traditional crops in Panimaquím, milpa was rotated with broccoli (Brassica oleracea var. italica) or snow peas (Pisum sativum). The year before the experiment was established, snow peas were grown in the plot.

The second site was in the town of Patzún at $2256 \mathrm{~m}$ above sea level. Guillermo Teleguario, the owner of the plot, planted his milpa in April or May, and harvested it in December. The fertilizer was cow manure dried in a pile and sieved before incorporation to the soil. When there was not enough cow manure, synthetic fertilizer (20-20-0) was used at a rate of $0.06 \mathrm{~kg}$ per "postura" $\left(567 \mathrm{~kg} \mathrm{ha}^{-1}\right), 3$ weeks after the germination of the corn, and urea (46-0-0) at a rate of $0.03 \mathrm{~kg}$ per "postura" $\left(283 \mathrm{~kg} \mathrm{ha}^{-1}\right)$ when the cobs started to form. Non-traditional crops had never been planted in this plot. The third site was located in Chimaltenango, the capital of the Department, at $1800 \mathrm{~m}$ above sea level. Until the late 1980s, ICTA agronomists focused their research on the production of new varieties of corn, beans, wheat, and potatoes. More recently, their mission shifted to reduction of pest damage in non-traditional crops, particularly broccoli, snow peas, and blackberries (Rubus sp.). Synthetic fertilizer is applied to all the crops in the experimental station. The experimental plot was established on a fallow covered with nut sedge (Cyperus rotundus).

All the agronomic practices, such as land preparation, seed selection, planting and weeding were prescribed by the farmers. This allowed the evaluation of fertilizer management in the context of other traditional practices. These same practices were also employed at the experimental station.

\subsection{Treatments}

During the first year, four treatments were evaluated in the three sites to determine their effects on herbivorous insects and their natural enemies in the milpa: (1) organic fertilizer as used by farmers (O), (2) synthetic fertilizer as used by farmers (FS), (3) synthetic fertilizer as recommended after soil chemical analysis (LS), and (4) control (no fertilizer applied) (C).

The amount and composition of fertilizer applied varied according to site conditions (Table 1). In Panimaquím and Patzún, differences between the effect of organic and synthetic fertilizers on pests were determined by comparing pests and pest damage between
Table 1

Fertilizers $\left(\mathrm{kg} \mathrm{ha}^{-1}\right)$ applied to corn plots in three sites (Guatemala)

\begin{tabular}{|c|c|c|c|c|c|c|}
\hline Site & Treatment & Fertilizers & $\mathrm{kg}$ & $\mathrm{N}$ & $\mathrm{P}$ & $\mathrm{K}$ \\
\hline \multicolumn{7}{|l|}{ First year } \\
\hline \multirow[t]{3}{*}{ Panimaquím } & $\mathrm{O}_{1}^{\mathrm{a}}$ & Compost & 2835 & 55 & 3 & 28 \\
\hline & $\mathrm{FS}^{\mathrm{b}}$ & $15-15-15$ & 425 & 64 & 64 & 64 \\
\hline & $\mathrm{LS}^{\mathrm{c}}$ & $46-0-0$ & 198 & 91 & 0 & ( \\
\hline \multirow[t]{7}{*}{ Patzún } & $\mathrm{O}_{1}$ & $\begin{array}{l}\text { Dry cow } \\
\text { manure }\end{array}$ & 2835 & 40 & 2 & 11 \\
\hline & FS & $20-20-0$ & 567 & 113 & 113 & \\
\hline & & $46-0-0$ & 284 & 130 & 0 & 0 \\
\hline & & Total FS & & 244 & 113 & 113 \\
\hline & LS & $46-0-0$ & 284 & 130 & 0 & ( \\
\hline & & $10-50-0$ & 142 & 14 & 71 & ( \\
\hline & & Total LS & & 145 & 71 & 0 \\
\hline \multirow[t]{5}{*}{ ICTA } & $\mathrm{O}_{1}$ & $\begin{array}{l}\text { Dry cow } \\
\text { manure }\end{array}$ & 2835 & 40 & 2 & 11 \\
\hline & $\mathrm{SRF}^{\mathrm{d}}$ & $24-4-7$ & 284 & 68 & 11 & 2 \\
\hline & LS & $46-0-0$ & 142 & 65 & 0 & \\
\hline & & $0-0-60$ & 37 & 0 & 0 & 22 \\
\hline & & Total LS & & 65 & 0 & 22 \\
\hline \multicolumn{7}{|l|}{ Second year } \\
\hline \multirow[t]{3}{*}{ Panimaquím } & $\mathrm{O}_{2}{ }^{\mathrm{e}}$ & Compost & 2835 & 55 & 3 & 2 \\
\hline & FS & $15-15-15$ & 425 & 64 & 64 & 64 \\
\hline & $\mathrm{O}_{1}$ & Compost & 2835 & 55 & 3 & 28 \\
\hline \multirow[t]{5}{*}{ Patzún } & $\mathrm{O}_{2}$ & $\begin{array}{l}\text { Dry cow } \\
\text { manure }\end{array}$ & 2835 & 40 & 2 & 11 \\
\hline & FS & $20-20-0$ & 567 & 113 & 113 & \\
\hline & & $46-0-0$ & 284 & 130 & 0 & \\
\hline & & Total FS & & 244 & 113 & \\
\hline & $\mathrm{O}_{1}$ & $\begin{array}{l}\text { Dry cow } \\
\text { manure }\end{array}$ & 2835 & 40 & 2 & 1 \\
\hline \multirow[t]{3}{*}{ ICTA } & $\mathrm{O}_{2}$ & $\begin{array}{l}\text { Dry cow } \\
\text { manure }\end{array}$ & 2835 & 40 & 2 & 1 \\
\hline & SRF & $24-4-7$ & 284 & 68 & 11 & 20 \\
\hline & $\mathrm{O}_{1}$ & $\begin{array}{l}\text { Dry cow } \\
\text { manure }\end{array}$ & 2835 & 40 & 2 & 11 \\
\hline
\end{tabular}

${ }^{a}$ Organic fertilizer applied for the first time.

b Synthetic fertilizer as recommended by farmers.

c Synthetic fertilizer as recommended by a soil laboratory.

${ }^{\mathrm{d}}$ Slow release fertilizer.

e Organic fertilizer applied for the second consecutive year.

treatments O, FS and C. Treatment LS was established to determine whether the expected differences were the result of inadequate amounts of $\mathrm{N}, \mathrm{P}$ or $\mathrm{K}$ in the synthetic fertilizer treatment, or to some other difference between synthetic and organic fertilization. In the ICTA, treatment $\mathrm{O}$ was cow manure as used in Patzún. Treatment FS, a slow release fertilizer (24-4-7), served to determine whether differences between 
synthetic and organic fertilizers were because of the slow release of nitrogen by the organic fertilizer.

Because some of the effects of organic fertilizers occur in the long term, a second experiment was established in the same plots a year later, evaluating the same treatments, with one modification. Instead of the LS treatment applied in year 1, the same compost was used as in treatment $\mathrm{O}$. This allowed comparison of the effects of organic fertilizer applied for the first time (treatment $\mathrm{O}_{1}$ ) after synthetic fertilizers, with organic fertilizer applied at least 2 years in a row (treatment $\left.\mathrm{O}_{2}\right)$.

\subsection{Design}

Treatments were arranged in a split plot randomized block design. Each of the three sites represents a block. Within each block there were three plots (replicates). Each plot was split into four subplots, each of which was assigned one of the four treatments (Neter et al., 1990). Each subplot was $5 \mathrm{~m} \times 5 \mathrm{~m}$, and was separated from the other plots by a $1 \mathrm{~m}$ border.

\subsection{Sampling}

During the first year, pest populations and their natural enemies were sampled every other week for the entire growing season (June-December). Adults and larvae of above-ground, herbivorous insects and their natural enemies were counted on 12 randomly selected "posturas" per plot. On the same plants, the percentage of aphids with symptoms of parasitism was estimated.

The only herbivorous insects sampled during the second year were the fall armyworm, Spodoptera frugiperda and the aphid, Rhopalosiphum maidis which according to farmers, had been a greater problem since the introduction of the non-traditional crops in the area (Morales et al., 1994). Furthermore, during the first year of this study, aphids were the only taxon that seemed to differ among treatments. The choice of these two species allowed comparison between responses of chewing and sucking insects. The second year, numbers of $S$. frugiperda larvae, $R$. maidis, and their natural enemies were determined based on 12 "posturas" per plot once a month during the entire growing season (June-December).Before the establishment of the experiment, soil was sampled by combining five soil sub-samples taken randomly within each plot. To determine the extent to which nutritional differences explain differences between fertilizer treatments, plant nutrient levels were monitored over time. Two months after the establishment of the experiments, leaves of all ages were sampled by cutting pieces from five corn plants randomly selected in each plot. Nutrient analysis was performed at the ICTA laboratory in Guatemala city. Total nitrogen, phosphorous, potassium, calcium, magnesium, sodium, iron, copper, manganese, and zinc were estimated from plant tissue for the first and second year.

Corn yield per plant and per plot at harvest was measured by weighing ears without husks produced by all the plants in each plot. The second year at harvest time the above-ground portion of three randomly selected plants per plot was also weighed. The mass of these plants was multiplied by the concentration of nutrients in the leaves of plants from each treatment, and its product was used as an index for comparison of the total nutrient content of plants across treatments to provide a better measure of plant nutritional status than nutrient concentration alone. Yield per plant and plot also was estimated for the second year, using all the plants in each plot.

\subsection{Statistical analysis}

A split plot ANOVA (Neter et al., 1990) was used to compare insect populations by site, treatment, and the interaction between treatments and sites. The pooled variance of the plots nested within sites was used as the error term to compare sites. The pooled variance of the plots nested within sites and treatments was used as the error term to compare treatments and the interaction between treatments and sites. Residual plots and Kolmogorov-Smirnov tests showed that the herbivorous insect data were neither normally distributed nor independent, even after a $\log (x+1)$ transformation. When the $p$ values were smaller than 0.01 or greater than 0.1 those violations were ignored, and the split plot ANOVA model was considered adequate. When the $p$ values were near $0.05(0.01>p>0.1)$ a two-way ANOVA was performed (Neter et al., 1990). In those cases, the effect of plots and treatments were evaluated for each site separately. All data analyzed with the two-way ANOVA were independent and normally distributed. 
A split plot ANOVA was used to compare natural enemy populations, percentage of aphid parasitism, plant nutrient concentrations, index of total nutrient per plant, biomass, and yields. None of these data required transformations because no normality violation was detected. Because ANOVA results for plant nutrient concentration and those for the index of total nutrient per plant were qualitatively identical for all of the nutrients, only the nutrient concentration analysis is presented in the results.

Linear regression was used to determine the association between $S$. frugiperda and $R$. maidis populations and corn leaf nutrient content for all the treatments combined. When differences in slope or intercept were detected among treatments, a separate regression analysis was performed for each treatment.

When ANOVA detected significant differences, means were separated using a Tukey's honestly significant difference test. Significance was accepted at the $5 \%$ level. Herbivorous insects, natural enemies, and percentage of aphid parasitism were analyzed using their average per plant across sampling dates for each treatment. All analyses were conducted using SPSS/PC version 7.5 (SPSS, 1997).

\section{Results}

\subsection{Herbivorous insects}

\subsubsection{First crop cycle}

During the first year of the experiment, six taxa of herbivorous insects were commonly encountered on the corn plants: Arctiidae, S. frugiperda, Curculionidae, and Diabrotica spp. were the most common chewing insects, and $R$. maidis and Cicadellidae were the most common sucking insects.

Throughout the crop cycle, the average number of herbivorous insects in all the plots remained low (five insects per plant), and they did not seem to be causing any economic damage, as farmers in Patzún stated (Morales and Perfecto, 2000). Although the number of herbivorous insects per plant was higher, on average, in FS plots, a two-way ANOVA for each site did not detect significant differences (Panimaquím: $F=2.71$, d.f. $=3,6, p=0.14$; Patzún: $F=2.59$, d.f. $=3,6, p=0.15$; ICTA: $F=1.29$, d.f. $=3,6$, $p=0.36)$.
The behavior of sucking and chewing herbivores was anticipated to differ in response to the fertilizer treatments. On average, the number of sucking insects was higher in the FS plots than in the $\mathrm{O}$ plots, but the differences were not significant at any of the sites (two-way ANOVA: Panimaquím: $F=2.84$, d.f. $=$ $3,6, p=0.13$; Patzún: $F=2.61$, d.f. $=3,6, p=$ 0.15; ICTA: $F=0.06$, d.f. $=3,6, p=0.98$ ). Likewise, no individual taxon responded significantly to the treatments. $R$. maidis was the most abundant herbivorous insect throughout the corn cycle, especially in FS plots, but differences were not significant at any of the sites (two-way ANOVA: Panimaquím: $F=2.84$, d.f. $=3,6, p=0.13$; Patzún: $F=3.77$, d.f. $=3,6$, $p=0.08$; ICTA: $F=3.76$, d.f. $=3,6, p=0.08$ ). The number of Cicadellidae was also higher in the FS plots, but again, the difference was not significant (split plot ANOVA: $F=1.69$, d.f. $=3,18, p=$ $0.20)$.

Populations of the fall armyworm, S. frugiperda, were low during the first year, and there were no differences among treatments (split plot ANOVA: $F=$ 1.7 , d.f. $=3,18, p=0.21$ ). Also none of the other three taxa of chewing insects seemed to be affected by the fertilization treatments.

\subsubsection{Second crop cycle}

$S$. frugiperda responded in the same way as during the first cycle: the population remained low (0.04 insects per plant) and did not differ among the treatments (split plot ANOVA: $F=0.48$, d.f. $=3,18, p=0.7$ ). $R$. maidis numbers per plant were significantly higher in FS $(19.18 \pm 6.23)$ and $\mathrm{O}_{1}(13.05 \pm 3.56)$ plots than in $\mathrm{O}_{2}(9.14 \pm 3.01)$ and $\mathrm{C}(7.45 \pm 1.95)$ plots (split plot ANOVA: $F=9.5$, d.f. $=3,18, p=0.001)$. Tukey's test did not detect any differences between the aphid populations in the FS and $\mathrm{O}_{1}$ plots, nor between $\mathrm{O}_{2}$ and $\mathrm{C}$.

\subsection{Foliar nitrogen and other nutrients}

\subsubsection{First crop cycle}

During the first crop cycle, the percentage of nitrogen in corn leaves was higher in FS (3.20 \pm 0.14$)$ and LS plants $(3.09 \pm 0.15)$ than in $\mathrm{O}(2.88 \pm 0.17)$ or C plants $(2.82 \pm 0.12)(F=9.14$, d.f. $=3,18$, $p=0.001)$. The regression analysis did not indicate any relationship between herbivorous insects and the 
percentage of nitrogen $\left(r^{2}=0.04, p=0.22\right)$. The concentration of foliar phosphorous, potassium, calcium, magnesium, sodium, iron, copper, manganese, and zinc was analyzed, but none of them differed among treatments.

\subsubsection{Second crop cycle}

Nitrogen concentration was higher in the FS plants $(2.97 \pm 0.26)$ than in the $\mathrm{O}_{2}(2.67 \pm 0.22)$ and $\mathrm{C}$ plots $(2.62 \pm 0.19)$ (split plot ANOVA: $F=3.69$, d.f. $=3,18, p=0.03$ ). A Tukey's test did not show any difference between the organic fertilizer applied for the first time $(2.88 \pm 0.25)$ and the other treatments. Regression analysis indicated a significant positive relationship between numbers of $R$. maidis and the concentration of nitrogen in plants $\left(r^{2}=\right.$ 0.56, $p<0.001$ ) (Fig. 1). However, for S. frugiperda the tendency was the opposite. The correlation was not very strong $\left(r^{2}=0.11, p=0.05\right)$, but suggested a negative relationship between $S$. frugiperda and nitrogen concentrations (Fig. 1).

Manganese levels also differed among plants subjected to the different fertilization regimes. Manganese was significantly higher in $\mathrm{O}_{1}$ plants $(46.67 \pm 13.72)$ than in $\mathrm{O}_{2}(30 \pm 4.08)$ or $\mathrm{C}$ plants $(31.11 \pm 3.89)$ $(F=4.49$, d.f. $=3,18, p=0.02)$. A Tukey's test found no difference in manganese concentrations between FS plants $(38.33 \pm 7.12)$ and plants in any of the other treatments.

Overall, aphid populations were not correlated with manganese concentrations $\left(r^{2}=0.25, p=0.14\right)$. Nevertheless, within the control treatment, populations of $S$. frugiperda were negatively correlated with manganese concentrations $\left(r^{2}=0.75, p=0.002\right)$ (Fig. 2).

During the second year, nutrient concentration data were combined with above ground biomass data to produce an index of plant nutrient content per plant. The split plot ANOVA's for nutrient content showed the same tendencies as for nutrient concentrations and did not vary significantly with treatment. As in the case of nitrogen concentration, the index for nitrogen content was significantly higher in the FS plots than in the $\mathrm{O}_{2}$ and $\mathrm{C}$ plots (split plot ANOVA: $F=3.77$, d.f. $=3,18, p=0.03$ ). A Tukey's test did not reveal any difference between $\mathrm{O}_{1}$ and the other treatments. The split plot ANOVA was similar for manganese content index and concentration. Manganese content index was higher in the $\mathrm{O}_{1}$ plants than in the $\mathrm{O}_{2}$ and C plants $(F=9.92$, d.f. $=3,18, p<0.001)$. Unlike results for manganese concentration, a Tukey's test also found significantly greater manganese content index in FS plants than in the $\mathrm{O}_{2}$ and $\mathrm{C}$ treatments.

\subsection{Slow release fertilization}

The slow release treatment applied at ICTA did not produce differences in foliar nitrogen concentration or insect response in comparison with the conventional synthetic treatment. The percentage of nitrogen in the plants treated with the conventional synthetic $(2.72 \pm 0.04)$ and slow release fertilizers $(2.58 \pm 0.03)$ was higher than in plants in the $\mathrm{O}(2.48 \pm 0.07)$ and C plots $(2.43 \pm 0.04)$ (two-way ANOVA: $F=8.07$, d.f. $=3,6, p=0.02$ ). According to a Tukey's test, the percentage of nitrogen was not different between plants treated with slow release and the conventional synthetic fertilizer, nor between plants in the $\mathrm{O}$ and $\mathrm{C}$ plots. There were no differences among treatments for any of the herbivorous insect populations (two-way ANOVA's: total pests: $F=1.29$, d.f. $=3,6, p=0.36$; chewing insects: $F=2.23$, d.f. $=3,6, p=0.19$; sucking insects: $F=0.06$, d.f. $=3,6, p=0.98$ ).

\subsection{Natural enemies}

Coccinellidae, Dermaptera and Araneae were the predators most often counted on the corn plants, and Braconidae was the only family of parasitoids present. There was no difference among first year treatments for the total population of natural enemies (all taxa combined, split plot ANOVA: $F=0.39$, d.f. $=3,18$, $p=0.76)$ nor in the percentage of parasitized aphids (split plot ANOVA: $F=0.2$, d.f. $=3,18, p=0.89$ ). However, during the second cycle, Coccinellidae populations were positively correlated with aphid numbers $\left(r^{2}=0.45, p<0.001\right)$ (Fig. 3). Nevertheless, the number of Coccinellidae was higher in the $\mathrm{O}_{1}(0.08 \pm$ $0.005)$ than in the FS plots $(0.04 \pm 0.002)$, where aphid populations were greater (split plot ANOVA: $F=$ 4.43 , d.f. $=3,18, p=0.008$ ).

\subsection{Corn yield and biomass}

Yields per plant and plot were estimated during the first and second crop cycles. For the first cycle, 


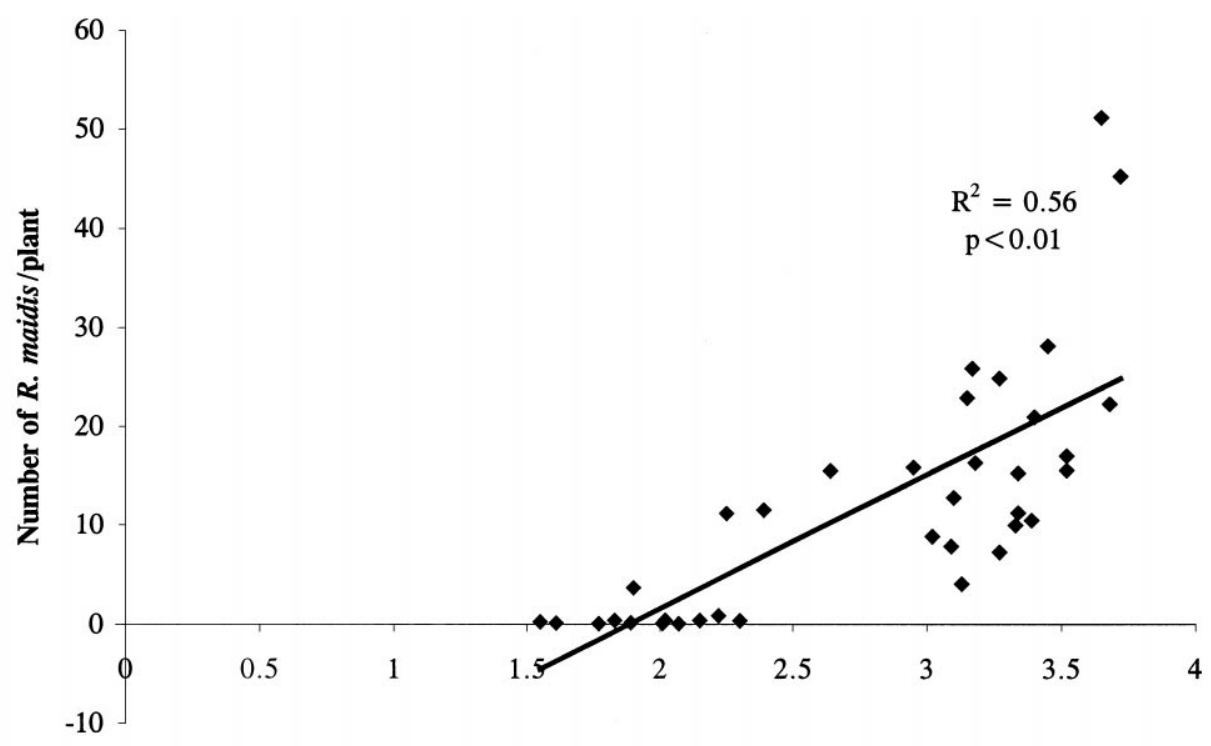

\% Nitrogen

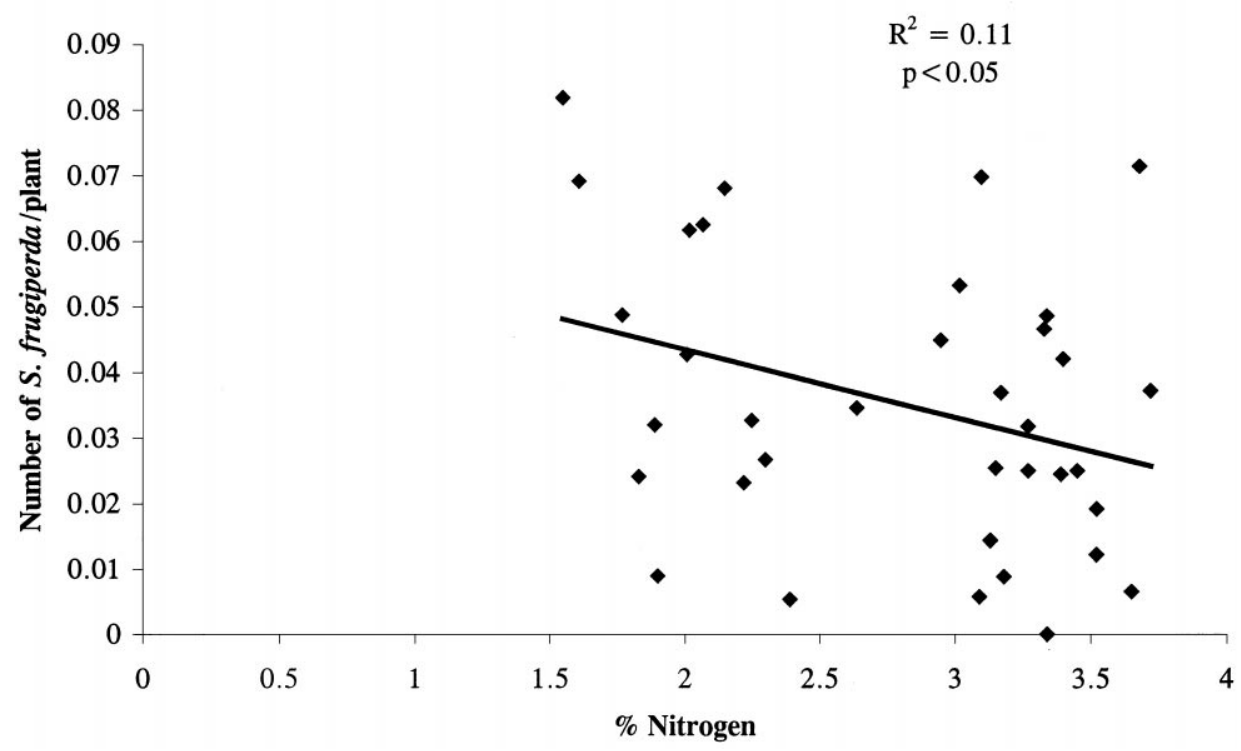

Fig. 1. R. maidis and S. frugiperda populations in relation to nitrogen concentration in corn leaves. Patzún, 1996. $r^{2}$ and $p$ values are from a linear regression analysis.

yields were very low $(0.23 \mathrm{~kg}$ per plant). There was no difference in yield per plant between treatments (split plot ANOVA: $F=0.26$, d.f. $=3,18$, $p=0.85$ ), nor in yield per plot (split plot ANOVA: $F=0.05$, d.f. $=3,18, p=0.99$ ). For the second cycle, yields were higher $(0.78 \mathrm{~kg}$ per plant), but there were still no differences between treatments (split plot ANOVA's: yield per plant: $F=2.50$, d.f. $=3,18$, $p=0.09$; yield per plot: $F=2.22$, d.f. $=3,18$, $p=0.12$ ). 


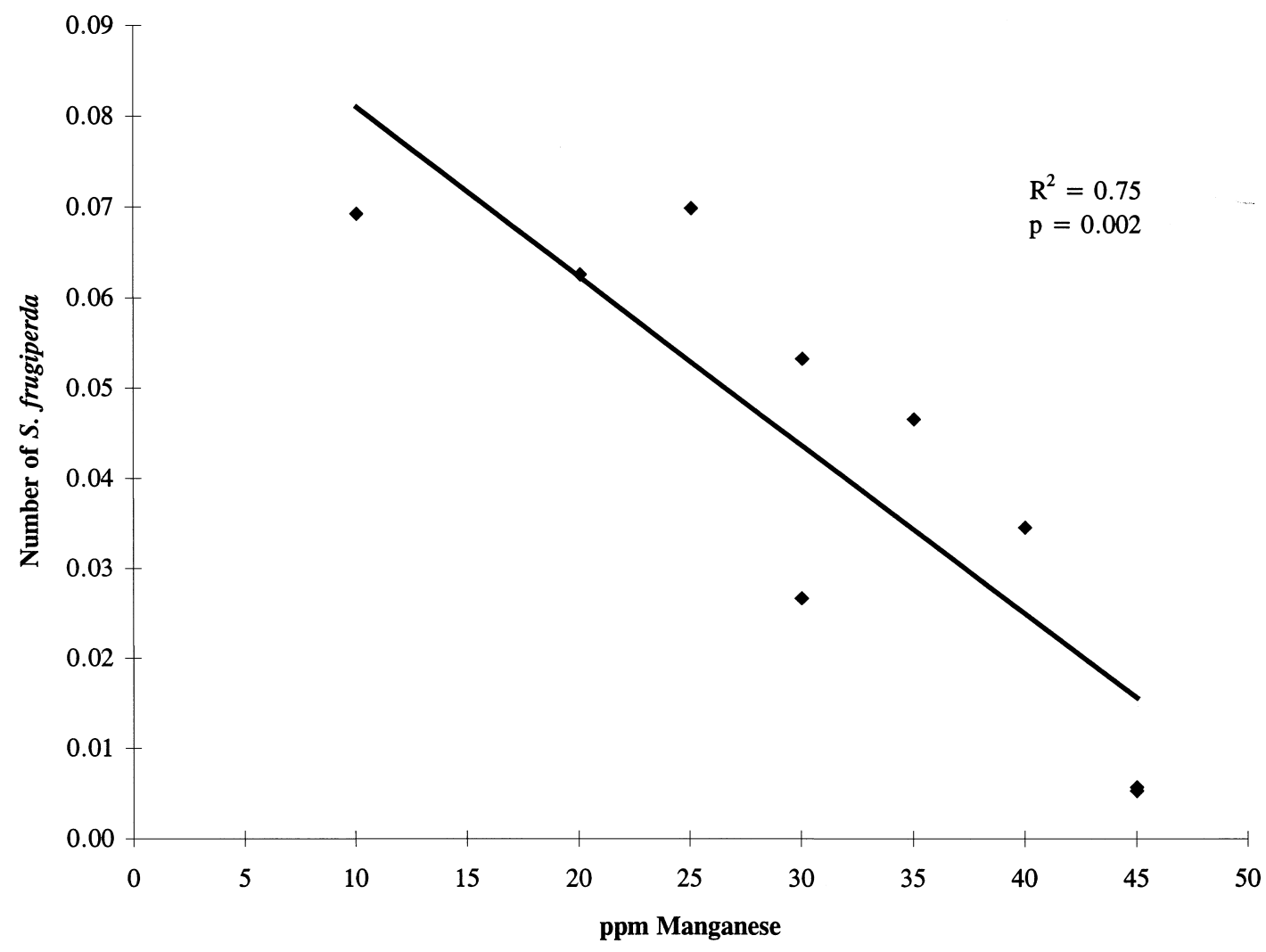

Fig. 2. S. frugiperda in relation to manganese concentration of corn leaves without fertilizer. Patzún, 1996. $r^{2}$ and $p$ values are from a linear regression analysis.

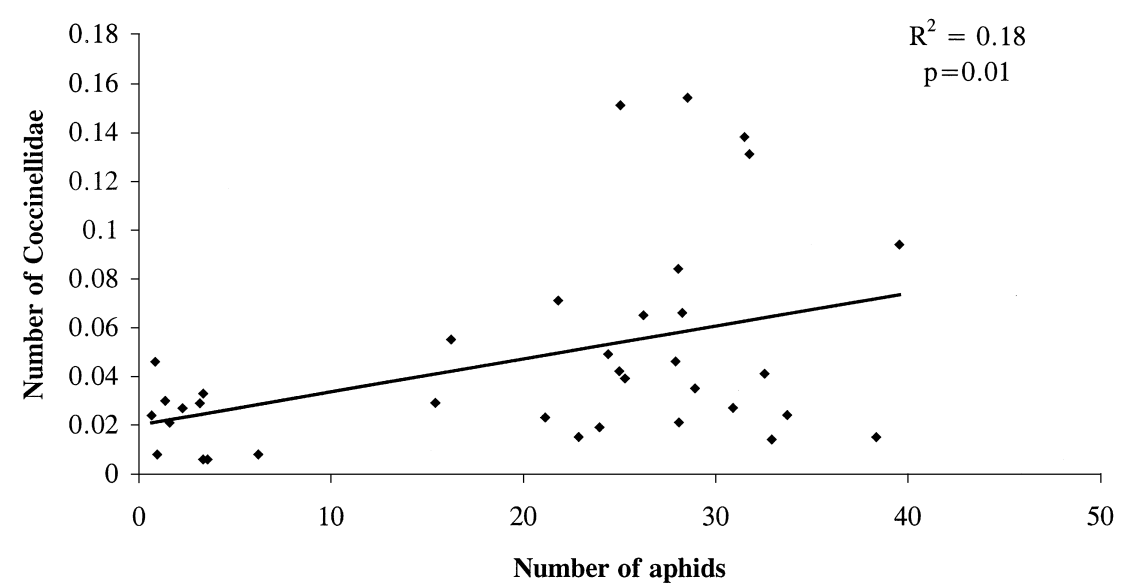

Fig. 3. Coccinellidae in relation to R. maidis on corn. Patzún, 1996. $r^{2}$ and $p$ values are from a linear regression analysis. 
For the second crop cycle biomass increased with the amount of nitrogen $\left(r^{2}=0.96, p<0.001\right)$, as expected, but did not differ between fertilizer treatments (split plot ANOVA: $F=0.95$, d.f. $=3,18$, $p=0.44)$.

\section{Discussion}

Herbivorous insects did not seem to be causing any economic damage in corn, as farmers in Patzún stated (Morales and Perfecto, 2000). Although most herbivorous insects did not respond distinctly to the different fertilizers, more $R$. maidis, occurred in corn plants treated with synthetic fertilizers, in agreement with farmers' observations.

Two ecological mechanisms might explain differences in pest response to synthetic and organic fertilizers: (1) a plant's nutritional status may influence its attractiveness to pests or its production of defenses; and (2) organic fertilizers may harbor natural enemies of pests.

Most studies have found that nitrogen has a positive impact on herbivorous insect populations, although others have produced equivocal results (Scriber, 1984; McGuinness, 1987). In the present experiment, $S$. frugiperda and $R$. maidis did respond to nitrogen content, but each in a different way.

The negative correlation between $S$. frugiperda and nitrogen corn content found in the present study, contrasts with the positive correlation found previously between $S$. frugiperda and other crops (Diawara et al., 1991; Davidson and Potter, 1995). Perhaps corn, like some other plants, produces more protein digestion inhibitors with increased nitrogen concentration (Raven, 1983; Herms and Mattson, 1992).

In contrast, the positive correlation between $R$. maidis populations and nitrogen concentration found in the present study concurs with results reported elsewhere (Van Emden and Bashford, 1969). What is new is that the differences in aphid populations between synthetic and organic plots seem to be the result of the higher amount of nitrogen that the synthetic fertilizers provided to the corn.

Manganese concentrations were high in the FS plants, even though the synthetic formula did not contain manganese. It may be that the urea applied to the $\mathrm{O}_{1}$ plots the year before, and to the FS plots, made the manganese in the manure and soil available to the plants. In any case, data suggest an inverse relationship between manganese and $S$. frugiperda populations in the control plots, in contrast to the findings of Grafton-Cardwell and Ouyang (1996), who found a positive correlation between manganese and mites. Perhaps manganese plays a role in plant defense, which plateaus at relatively low concentrations, but this effect is counteracted at higher concentrations by the contribution of manganese to herbivore nutrition.

Besides nutrient concentrations, optimum fertilization, which provides a proper balance of elements, stimulates resistance to insect attack (Howard, 1943; Teetes, 1980). Organic nitrogen sources may allow greater tolerance of vegetative damage because they release nitrogen more slowly, over the course of several years (Dick and McCoy, 1993). The amount of nitrogen immediately available may be lower when organic fertilizers are applied, but the overall nutritional status of the crop may be improved. Based on the nutrient content of corn plants, it appears that nutrients were released more quickly from slow release synthetic fertilizer than from organic fertilizer. Thus no conclusions can be drawn as to whether differences in pest response to fertilizer treatments are explicable by rate of nutrient release.

An important finding is that differences in aphid response were significant only after the second year of organic fertilization. The lack of significant differences among first year treatments supports growing evidence that the effects of organic fertilizers on soils and plants are detectable only in the long term (Culik, 1983; Scow et al., 1994; Phelan et al., 1995). The explanation in this case, however, does not seem to be the long-term effect of the organic fertilizer. There were no differences between organic fertilizer and the control but data suggest that the effect of synthetic fertilizers on aphids lasts for at least 1 year after application and is cumulative.

Fertilizer treatments may also influence pest populations through their effects on natural enemies. Previous studies also found higher natural enemy populations in crops treated with organic fertilizers. Organic fertilizers contain micro-organisms (nematodes, bacteria, fungi) that may suppress soil-dwelling insect pests and may provide more favorable habitat for epigaeic predators of pests (Dritschilo and Wanner, 1980). Purvis and Curry (1984) suggest that the 
supply of saprophagous fauna in compost may favor the natural enemies that feed on them as well as on pests. Animal manure may also increase natural enemy populations by affecting foliar density, and thus microclimate and surface activity of the natural enemies (Chiang, 1970; Honek and Holopainen, 1986).

Fertilization techniques may also influence natural enemy populations by their contribution to infochemical production. Corn produces infochemicals that attract natural enemies when the plants suffer herbivory (Dicke, 1994), and the infochemicals in some crops are affected by abiotic factors such as water stress, light intensity, and season (Takabayashi et al., 1994). Nutrient levels may also influence infochemical production. However, with the exception of plant biomass as a proxy for foliage density none of these potential influences on Coccinellidae populations could be evaluated in the present study.

Surprisingly, the significant differences in herbivore populations and foliar nutrient concentrations among treatments had no apparent effects on corn yield and biomass. The lack of yield and biomass response to fertilizer treatments, may be due to the natural fertility of the volcanic soils in the area. Alternatively, even after 2 years without fertilizer, the effect of previous fertilization and the incorporation of harvest residues into the soil, may have augmented yields in the control plots. Were corn yields simply unaffected by higher aphid populations in the synthetic fertilizer plots or was increased pest damage in those plots compensated for by the increased nutrients afforded by the fertilizer? In any case, it seems that the application of synthetic fertilizer is not economically beneficial in this area. The average cost of synthetic fertilizer as applied by farmers in Patzún was 4.8 times greater than that of organic fertilizer $\left(\mathrm{SF}=\mathrm{US} \$ 258.62 \mathrm{ha}^{-1} \mathrm{vs}\right.$. $\mathrm{O}=\mathrm{US} \$ 53.87 \mathrm{ha}^{-1}$ ). Greater labor input is required for transportation and application of organic fertilization, but labor is cheap in Guatemala, so these costs are minimal. In fact, however, the data suggest that no fertilization is necessary. Nevertheless, the lack of fertilization may be detrimental in the long term.

\section{Acknowledgements}

The authors express gratitude to John Vandermeer, John Witter, Roger Williams, and the New World
Agricultural and Ecology Group for providing insightful ideas and criticism; to Gary Fowler and Charles MacVean for statistical advice; to Daniel Engelberg, John Soluri, Amy Crosson, Ryan Golten, Michael Mann, Ana Upón, Margarito and Mario Raquec, Cristina and Gilberto Mérida, and Lily Morales for help with the field work; to Margarita de Colocho, Rigoberto Castañeda, Rodolfo Ortíz and Tanea Ramos for help with the soil and plant chemical analysis; to Alejandro Cipac and Guillermo Teleguario for sharing knowledge and access to their plots to establish the experiment; to The Institute of Agricultural Science and Technology of Guatemala (ICTA) for use of the facilities of the experimental station; to Fulbright-LASPAU, IPM-CRSP/USAID, the Rackham School of Graduate Studies and the School of Natural Resources and Environment at The University of Michigan for providing funds through grants to Helda Morales; to the two anonymous referees and the Editor-in-Chief for useful comments on the manuscript.

\section{References}

Altieri, M., 1984. Towards a grassroots approach to rural development in the Third World. Agric. Hum. Val. 1, 45-48.

Chiang, H., 1970. Effects of manure applications and mite predation on corn rootworm populations in Minnesota. J. Econ. Entomol. 63, 934-936.

Costello, M., 1994. Broccoli growth, yield and level of aphid infestation in leguminous living mulches. Biol. Agric. Hort. 10, 207-222.

Costello, M., Altieri, M., 1995. Abundance, growth rate and parasitism of Brevicoryne brassicae and Myzus persicae (Homoptera: Aphidae) on broccoli grown in living mulches. Agric. Ecosyst. Environ. 52, 187-196.

Culik, M., 1983. The conversion experiment: reducing farming costs. J. Soil Water Conserv. 38, 333-335.

Culliney, T., Pimentel, D., 1986. Ecological effects of organic agricultural practices on insect populations. Agric. Ecosyst. Environ. 15, 253-266.

Davidson, A., Potter, D., 1995. Response of plant-feeding, predatory, and soil-inhabiting invertebrates to Acremonium endophyte and nitrogen fertilization in tall fescue turf. J. Econ. Entomol. 88, 367-379.

De Walt, B., 1994. Using indigenous knowledge and natural resource management to improve agriculture and natural resource management. Hum. Organ. 53, 123-131.

Diawara, M., Hill, N., Wiseman, B., Isenhour, D., 1991. Penicle stage resistance to Spodoptera frugiperda (Lepidoptera: Noctuidae) in converted sorghum accessions. J. Econ. Entomol. 84, 337-344. 
Dick, W., McCoy, E., 1993. Enhancing soil fertility by addition of compost. In: Hoitink, H., Keener, H. (Eds.), Science and Engineering of Composting: Designing, Environmental, Microbiological and Utilization Aspects. The Ohio State University, Wooster, OH, pp. 622-644.

Dicke, M., 1994. Local and systemic production of volatile herbivore-induced terpenoids: their role in plant-carnivore mutualism. Plant Physiol. 143, 465-472.

Dritschilo, W., Wanner, D., 1980. Ground beetle abundance in organic soil and conventional corn fields. Environ. Entomol. 9, 629-631.

Eigenbrode, S., Pimentel, D., 1988. Effects of manure and chemical fertilizers on insect pest populations on collards. Agric. Ecosyst. Environ. 20, 109-125.

Grafton-Cardwell, E., Ouyang, Y., 1996. Influence of citrus leaf nutrition on survivorship, sex ratio, and reproduction of Euseius tularensis (Acari: Phytoseidae). Environ. Entomol. 25, 10201025.

Herms, D., Mattson, W., 1992. The dilemma of plants: to grow or defend. Quart. Rev. Biol. 67, 283-333.

Hoitink, H., Boehm, M., Hadar, Y., 1993. Mechanisms of suppression of soilborne plant pathogens in compost-amended substrates. In: Hoitink, H., Keener, H. (Eds.), Science and Engineering of Composting: Designing, Environmental, Microbiological and Utilization Aspects. The Ohio State University, Wooster, OH, pp. 601-621.

Honek, A., Holopainen, H., 1986. Carabid species and activity densities in biologically and conventionally managed cabbage fields. J. Appl. Entomol. 102, 253-363.

Howard, A., 1943. An Agricultural Testament. Oxford University Press, London, $253 \mathrm{pp}$.

Letourneau, D.K., Drinkwater, L., Shennan, C., 1996. Effects of soil management on crop nitrogen and insect damage in organic vs. conventional tomato fields. Agric. Ecosyst. Environ. 57, 179-187.

Lightfoot, D., Whitford, W., 1987. Variation in insect densities on desert creosotebush: is nitrogen a factor. Ecology 68, 547-557.

Listinger, J., 1993. A farming systems approach to insect pest management for upland and lowland rice farmers in tropical Asia. In: Altieri, M. (Ed.), Crop Protection Strategies for Subsistence Farmers. Westview Press, Boulder, CO, pp. $45-103$.

McGuinness, H., 1987. The importance of plant diversity and the nutritional content of the diet on the population dynamics of herbivorous insects. Ph.D. Dissertation. Biology Department, The University of Michigan, Ann Arbor, MI.

Morales, H., 1998. Pest control and soil management in the Guatemalan highlands: understanding traditional agricultural practices. Ph.D. Dissertation. School of Natural Resources and Environment, The University of Michigan, Ann Arbor, MI.

Morales, H., Perfecto, I., 2000. Traditional knowledge and pest control in the Guatemalan highlands. Agric. Hum. Val. 1, 4963.

Morales, H., Pérez, R., MacVean, C., 1994. Impacto ambiental de los cultivos no tradicionales en el altiplano de Guatemala. Textos de Debate. AVANCSO, Guatemala.

Neter, J., Wasserman, W., Kutner, M., 1990. Applied Linear Statistical Models. Irwin, Boston, MA.

Phelan, P., Mason, J., Stinner, B., 1995. Soil-fertility management and host preference by European corn borer, Ostrinia nubilalis (Hubner), on Zea mays L.: a comparison of organic and conventional chemical farming. Agric. Ecosyst. Environ. 56, 1-8.

Purvis, G., Curry, J., 1984. The influence of weeds and farmyard manure on the activity of Carabidae and other ground-dwelling arthropods in a sugar beet crop. J. Appl. Ecol. 21, 271-283.

Raven, J., 1983. Phytophages of xylem and phloem: a comparison of animal and plant sap-feeders. Adv. Ecol. Res. 13, 135-234.

Scow, K., Somoasco, O., Gunapala, N., Lau, S., Venette, R., Ferris, H., Miller, R., Shennan, C., 1994. Transition from conventional to low-input agriculture changes soil fertility and biology. Calif. Agric. 48, 21-27.

Scriber, J., 1984. Nitrogen nutrition of plants and insect invasion. In: Hauck, R. (Ed.), Nitrogen in Crop Production. American Society of Agronomy, Madison, WI.

SPSS Inc., 1997. Statistical Program for the Social Sciences, SPSS/PC, Version 7. SPSS Inc., Chicago, IL.

Takabayashi, J., Dicke, M., Posthumus, M., 1994. Volatile herbivore-induced terpenoids in plant-mite interactions: variation caused by biotic and abiotic factors. J. Chem. Ecol. 20, 1329-1354.

Teetes, G., 1980. Breeding sorghums resistant to insects. In: Maxwell, F., Jennings, P. (Eds.), Breeding Plants Resistant to Insects. Wiley, New York, pp. 457-485.

Van Emden, H., Bashford, M., 1969. A comparison of the reproduction of Brevicoryne brassicae and Myzus persicae in relation to soluble nitrogen concentration and leaf age (leaf position) in the brussels sprout plant. Entomol. Exp. Appl. 12, 351-364. 